\title{
HUMa ORANG BADUY dALAM PEMBENTUKAN SIKAP SWASEMBADA paNGAN
}

\author{
BADUY'S HUMA IN THE SENSE OF FOOD SELF-SUPPORTING \\ Yudi Putu Satriadi \\ Balai Pelestarian Nilai Budaya Bandung \\ Jln. Cinambo No.136 Ujungberung-Bandung 42094 \\ e-mail: yuputsatriadi@gmail.com
}

\begin{abstract}
Abstrak
Penelitian ini bertujuan untuk mengkaji peran budaya lokal dalam mendukung program ketahanan pangan. Penelitian dilakukan di daerah Baduy menggunakan metoda survei, observasi, wawancara mendalam dan analis deskriptif. Fokus kajian dilakukan terhadap huma sebagai sumber penghasil pangan untuk memenuhi kebutuhan keluarga. Hasil penelitian menunjukkan bahwa huma sebagai sumber penghasil pangan diatur pengelolaannya mengikuti adat yang dilestarikan dengan beberapa kriteria yaitu mempertahankan tata ruang melalui pembatasan perubahan tata guna lahan; memerhatikan waktu yang diperlukan untuk pengembalian status nutrisi lahan dan optimasi komponen biotik dan abiotik untuk mendukung produksi; mempertahankan komponen ekosistem untuk mendukung produktivitas huma, meminimalisasi biaya produksi melalui pembatasan pengolahan lahan, tidak merokok, mengurangi pembicaraan yang tidak produktif, lebih mengefisienkan waktu kerja, serta mengatur peruntukan padi dan beras dengan pengaturan pendistribusian yang ketat. Penelitian ini memberikan 3 rekomendasi yaitu (i) kearifan lokal tetap dipertahankan dengan memerhatikan kemajuan ilmu pengetahuan dan teknologi untuk mendukung swasembada pangan; (ii) menyesuaikan daya dukung lingkungan dengan program eksploitasi; (iii) menyusun tata ruang berdasarkan potensi penggunaan lahan dan kajian sosial budaya.
\end{abstract}

Kata kunci: huma, Baduy, pola tradisional, swasembada pangan.

\begin{abstract}
This study aims to assess the role of local culture in supporting security programs of food self-supporting in the Baduyarea. This research conducted a survey method, observation, in-depth interviews and descriptive analysis. This study focusonhuma as a source of food to meet the needs of the family. The results showed that the huma as a source of food is set to follow the traditional management preserved with some criteria.They are: maintaining spatial through the restrictions on land use changing, paying attention to the time required for returning the nutritional status of the land and optimizingthe biotic and abiotic components to support production, maintaining ecosystem components to support huma productivity, minimizing production costs through restrictions on land management, not smoking, reducing unproductive talks, being more efficient in working time, as well as regulating the allotment of rice and rice with a tightdistribution. This study provides three recommendations: (i) local knowledge is maintained by taking into account the advancement of science and technology to support food self-sufficiency; (ii) adjusting the carrying capacity of the environment to the exploitation program; (iii) developing spatial based on potential land use and socio-cultural studies.
\end{abstract}

Keywords: huma, Baduy, Traditional pattern, food self-supporting. 


\section{A. PENDAHULUAN}

Pertambahan penduduk yang sangat cepat terutama di negara berkembang memacu peningkatan kebutuhan pangan (Patel, 2012:1). Malahan bukan hanya peningkatan kebutuhan pangan tetapi juga lahan untuk sumber pangan itu. Kebutuhan lahan saat ini menjadi permasalahan tersendiri di tengah-tengah banyaknya alih fungsi lahan pertanian untuk permukiman dan kebutuhan lainnya. Dengan makin bertambah banyaknya penduduk Kanekes, terutama orang panamping, luas lahan huma mereka tidak mencukupi lagi. Oleh karena itu, akhir-akhir ini banyak orang Kanekes menyewa lahan huma di daerah luar Kanekes. Sewa-menyewa lahan huma tersebut ada yang berdasarkan sistem bagi hasil dan ada pula yang benar-benar menyewa dengan uang. Selain itu, ada pula sejumlah penduduk Kanekes ditempatkan oleh pemerintah di luar daerah Kanekes, yaitu Gunung Tunggal, menempati area bekas perkebunan. Di tempat pemukiman baru itu disediakan lahan huma (Edi S. Ekajati, 1995:95). Masalah ketersediaan pangan di Indonesia, menjadi semakin krusial seiring dengan terus bertambahnya jumlah penduduk, melonjaknya harga kebutuhan bahan makanan pokok dan menurunnya tingkat produktivitas lahan pertanian. Salah satu penyebab menurunnya produktivitas lahan pertanian adalah penggunaan pestisida dan pupuk kimia yang berlebihan. Lahan pertanian yang terus dipupuk kimia secara berlebihan hanya menunjukkan respons seketika, tetapi berdampak cepat habisnya bahan organik tanah dan meracuni tanah sehingga tanah menjadi sakit (Murdiyarso dalam Zamroni, 2010:72). Sejumlah petani konvensional di Jawa memiliki ketergantungan yang sangat tinggi terhadap bibit unggul, pupuk kimia, dan pestisida. Ironisnya, mereka malah justru meninggalkan bibit lokal yang lebih tahan terhadap serangan hama (wereng). Akibat penggunaan bibit nonlokal tersebut, subsektor tanaman pangan rentan terhadap berbagai hama, petani menjadi bodoh dengan melupakan banyak pengetahuan lokal dan menggantungkan diri pada paketpaket teknologi pertanian produk industri (Noertjahyo dalam Zamroni, 2010:73). Penggunaan pestisida alami dipandang lebih arif mengingat penggunaan pestisida sintetis ternyata berdampak buruk, antara lain munculnya ketahanan hama terhadap pestisida, membengkaknya biaya produksi untuk membeli pestisida serta timbulnya dampak negatif penggunaan pestisida terhadap manusia, lingkungan, dan ternak (Sintia dalam Octavia, 2008:355).

Sementara di lain pihak kehidupan beberapa masyarakat yang memegang adat tradisional mampu mempertahankan kelangsungan kehidupan melalui penerapan kearifan lokal (Berkes, Colding, dan Folke 2000: 1251). Masyarakat Baduy telah menerapkan prinsip pengelolaan lingkungan yang selaras dengan daya dukung lingkungan dan sesuai dengan kebutuhan masyarakat adat yang memegang teguh kelestarian ekosistem (Permana, Nasution, and Gunawijaya 2011: 67). Oleh karena itu penelitian ini bertujuan mengkaji kembali salah satu pengetahuan tradisional dari suku Baduy yang dapat dijadikan sebagai salah satu acuan dalam penyediaan pangan yang memerhatikan kelestarian ekosistem dan keberlangsungan jasa ekosistem (Khomsan dan Wigna 2009: 97). Dalam menjalani kehidupan, orang Baduy terikat oleh aturan atau norma sesuai dengan kepercayaan yang dianut oleh mereka yaitu Sunda Wiwitan. Ajaran Sunda Wiwitan telah dianut dan digunakan sejak dahulu ketika karuhun mereka hidup dan mendiami tanah Baduy dan dijadikan pedoman dalam kaitannya kehidupan dengan sesama manusia atau kehidupan dengan Sang Pencipta. Konsep terpenting dan menjadi inti perilaku masyarakat Baduy dengan 'agama' dan kepercayaan Sunda Wiwitan adalah kesederhanaan. Pandangan hidup yang senantiasa menjadi pedomannya bahwa aturan dan ketentuan yang telah diterima secara turun-temurun tidak boleh diubah, harus diterima sesuai dengan yang 
disampaikan oleh para pendahulunya (Suhada, 2005:1).

Orang bertani di Priangan dan Sunda lainnya, mereka berusaha menggunakan adat berterima kasih, menaruh perhatian kepada yang membuat kesenangan, misalnya pohon-pohon yang besar, sumber air, batu-batu yang belum pernah diganggu manusia, makam-makam kuno. Kesemuanya telah terasa manfaatnya, air berkecukupan, pohon enau telah terasa gulanya (H. Hasan Mustapa, 2010:103).

Istilah Baduy atau Urang Baduy adalah sebutan yang diberikan oleh orang luar. Masyarakat Baduy merupakan salah satu komunitas sosial yang berada di wilayah Desa Kanekes Kecamatan Leuwidamar Kabupaten Lebak. Kanekes merupakan nama desa yang sebagian besar dihuni oleh warga Baduy. Masyarakat Baduy Dalam yang biasa disebut Urang Tangtu, mendiami wilayah-wilayah Kampung Cikeusik yang disebut Tangtu Pada Ageng; Warga Baduy yang mendiami Kampung Cibeo yang disebut Tangtu Parahiang; dan Warga Baduy yang mendiami Kampung Cikertawana yang disebut Tangtu Kadu Kujang.

Tugas hidup warga Baduy yang disebut Urang Tangtu adalah "bertapa", maksudnya tidak mengubah perilaku dan menjaga lingkungan alam yang telah diwasiatkan oleh leluhurnya. Hal tersebut tercermin dalam kehidupan sehari-hari yang tidak menggunakan sabun, pasta gigi, atau bahan lainnya yang membahayakan alam. Masyarakat Baduy lainnya adalah Baduy Panamping dan Baduy Dangka, disebut oleh orang-orang sebagai Baduy Luar. Masyarakat Baduy Luar ini mendiami 53 kampung. Tugas masyarakat Luar adalah menjaga orang yang sedang "bertapa" (Urang Tangtu) sekaligus membantu menjaga kelangsungan adat. Tugas hidup tersebut terlihat pada pola perilaku mereka. Masyarakat Baduy Luar relatif lebih terbuka dibandingkan dengan Urang Tangtu, sebab mereka dihadapkan langsung pada pengaruh-pengaruh eksternal.
Pembeda utama antara Urang Tangtu dengan Baduy Luar, selain letak wilayah pemukiman, juga diperlihatkan dengan pakaian yang dikenakan serta kebiasaan pergi ke luar daerahnya. Warga Urang Tangtu menggunakan pakaian dan iket kepala serba putih dan selalu berjalan kaki, sedangkan Baduy Luar menggunakan pakaian serba hitam dan boleh menggunakan kendaraan.

Kaitannya dengan ruang produksi, di antaranya huma dianggap sebagai lahan 'suci' yang pengolahannya tidak boleh dilakukan dengan sembarangan. Semua tahapan pengolahan harus sesuai dengan ketentuan yang telah dilakukan secara turun-temurun. Ketentuan tersebut tidak boleh dilanggar. Jika dilanggar akan terkena bebendon yang sangat menakutkan dan akibatnya akan merugikan pelanggar. Bebendon ini bukan hanya mengena kepada pribadi pelanggar bahkan bisa mengenai seluruh warga kampung. Sebagai bentuk ketaatan masyarakat Baduy terhadap Sang Maha Pencipta, dalam mengolah huma tidak pernah dilepaskan dari upacara. Upacara-upacara yang dilakukan oleh masyarakat Baduy sangat banyak, namun secara umum senantiasa berhubungan dengan aktivitas pertanian/berladang (ngahuma). Di Baduy tidak ditemukan sawah karena dilarang mengolah tanah dengan menggunakan cangkul, ditambah lahan di daerah Baduy merupakan pegunungan yang rentan terhadap longsor manakala dijadikan lahan persawahan (Permana, Nasution, dan Gunawijaya, 2011: 67).

Huma adalah tanah pertanian berupa ladang padi dan palawija yang sehabis panen ditinggalkan (dibiarkan tidak digarap sehingga tanah berhumus kembali), sementara si penggarap berpindah-pindah dari tanah yang satu ke tanah yang lain pada musim-musim cocok tanam selanjutnya, baik dengan membuka tanah ladang baru (membabat hutan) maupun dengan menggarap kembali tanah ladang yang telah lama ditinggalkan (Ayip Rosidi, 2000: 275). Pengolahan huma 
dilakukan secara tradisional, yakni dilakukan menurut tradisi (KBBI, 2013: 1483)

Masyarakat Baduy menaati seluruh pantangan atau tabu yang tidak boleh dilakukan di huma. Huma tidak boleh dicangkul; huma tidak boleh diinjak kerbau; dan huma tidak boleh digarap dengan menggunakan bajak. Pantangan atau larangan lain yang terkait dengan huma tampak dalam setiap tahapan mengolah huma yang tidak boleh meludah, tidak boleh merokok, tidak boleh kentut, tidak boleh berbicara kasar atau kotor, dan tidak boleh menggunakan pakaian yang kotor. Bagi laki-laki harus menggunakan iket, dan menaati akan ketentuan hari-hari pantangan bekerja di ladang atau huma yakni pada hari Selasa, Jumat, dan Minggu. Esensi dari aturan tersebut adalah lebih mengefisienkan input untuk semua proses produksi sebagai implementasi dari konsep "low carbon society" (Zeng, 2011: 15). Proses mengolah huma sama dengan membuka lahan baru karena huma yang telah ditanami sebelumnya akan ditinggalkan dalam waktu cukup lama. Dengan demikian, pada lahan tersebut telah tumbuh kembali rerumputan yang cukup tinggi serta pohon-pohon pun tumbuh cukup besar dan tinggi.

Selain berlaku tabu, seluruh tahapan pengolahan huma tidak terlepas dari upacara. Upacara dalam bidang pertanian (huma) dilakukan di huma serang yang terdapat di wilayah Urang Tangtu atau Baduy Dalam. Pelaksanaan upacara di lahan huma serang tersebut dianggap sebagai pengesahan untuk huma-huma lainnya milik penduduk. Tata cara pengolahan huma milik penduduk di luar Baduy Dalam lainnya akan dan harus sama dengan tata cara yang telah dilakukan di huma serang, sekalipun upacara yang menyertainya tidak mutlak diikuti.

\section{B. METODE PENELITIAN}

Untuk mengkaji peran budaya dan kearifan lokal masyarakat Baduy dalam penyediaan pangan, dilakukan penelitian pengelolaan huma secara tradisional di daerah Baduy dengan menggunakan metoda survei, wawancara mendalam dan analis deskriptif. Survei dilakukan untuk mengamati lokasi huma yang dijadikan objek garapan pertanian. Wawancara dilakukan dengan penduduk Baduy Luar yang mengetahui segala tata cara pengolahan huma serang. Fokus kajian dilakukan terhadap huma sebagai sumber penghasil pangan untuk memenuhi kebutuhan keluarga.

\section{HASIL DAN BAHASAN}

Tahapan mengolah huma diatur dengan susunan yang sudah tentu dan dilakukan secara turun-temurun sejak dahulu. Tahapan tersebut tidak boleh ditukar atau dilewatkan. Dalam setiap tahapan mengolah huma selalu disertai dengan upacara sehingga nama kegiatan pengolahan huma disebut sama dengan nama upacaranya. Dalam pelaksanaan seluruh kegiatan pengolahan dan upacara di huma serang terdapat tabu atau larangan tidak boleh kentut, meludah, merokok, berkata kotor, melakukan kegiatan pada hari pantangan bekerja di huma, pelaku kegiatan laki-laki harus menggunakan iket kepala, perempuan menggunakan kain kebaya. Tahapan mengolah huma mulai dari tahapan paling awal hingga selesai adalah sebagai berikut:

\section{Narawas}

Narawas merupakan tahapan paling awal dalam mengolah huma, yang menandai dibukanya huma. Pola pelaksanaan kegiatannya sudah baku dan turun-temurun. Ketaatan terhadap aturan yang tidak boleh mengubah tata upacara, menyebabkan penduduk Baduy tidak mengetahui awal mula pelaksanaan upacara dalam kegiatan narawas ini. Kegiatan narawas perlu dilakukan karena huma yang sengaja mereka tinggalkan dalam waktu cukup lama telah ditumbuhi kembali rerumputan serta pohon-pohon sudah besar. Jika tidak dibersihkan, keadaan rerumputan yang tinggi akan 
mengganggu pertumbuhan padi, serta pohon-pohon besar akan menghalangi sinar matahari yang diperlukan tanaman padi. Mereka tidak berani melakukan kegiatan narawas tanpa upacara apalagi tidak melakukan kegiatan ini. Mereka takut akan kena bebendon yang berakibat terjadinya kecelakaan atau tanaman padi di huma tidak berhasil. Kegiatan dan upacara ini diturunkan secara turun-temurun dari satu generasi kepada generasi selanjutnya dengan cara mencontohkan dan mewajibkan seluruh warga Baduy untuk melaksanakan. Begitu juga kepada orang yang diberi tugas untuk memimpin upacara ini diwajibkan menaati aturan dan tata cara yang sudah berlangsung.

Kegiatan narawas dilaksanakan pada bulan kesatu menurut penanggalan Baduy. Bulan tersebut jatuh pada sekitar bulan Sapar. Dilakukan pada pagi hari sampai dengan siang hari. Waktu yang ditentukan melalui musyawarah para sesepuh Baduy, yang tidak dapat diubah sekalipun kegiatan tersebut bertepatan dengan hari-hari besar keagamaan atau kenegaraan.

Tempat penyelenggaraan upacara narawas di huma serang 'ladang suci'. Kegiatan ini tidak dapat dipindahkan lagi ke tempat lain.

Upacara narawas dipimpin oleh girang seurat. Apabila girang seurat berhalangan karena sakit dan hal lainnya, maka upacara dipimpin oleh orang yang jabatannya setingkat dengan girang serat setelah mendapat persetujuan dari pu'un.

Jalannya upacara diawali oleh girang seurat berdoa. Setelah selesai berdoa, dia memulai membersihkan rumput, perdu, dan memotong ranting pohon besar yang ada di huma serang. Selanjutnya, perwakilan keluarga dari kampung-kampung yang menginduk kepada kasepuhan Baduy mengikuti langkah-langkah yang dilakukan girang seurat.

\section{Nyacar}

Kegiatan nyacar merupakan kegiatan tahap kedua setelah narawas. Kegiatan ini dinamai nyacar, dalam bahasa Baduy, sama juga dengan bahasa Sunda, nyacar artinya memotong-motong.

Kegiatan nyacar bertujuan untuk memotong-motong ranting atau dahan yang panjang, yang telah dipotong pada saat kegiatan narawas. Dengan cara dipotong-potong, dahan yang panjang menjadi bagian-bagian lebih pendek sehingga dahan tersebut akan cepat mengering dan memudahkan terjadinya penyerapan dari unsur dahan tersebut untuk penyediaan nutrisi tanaman.

Tidak terdapat persiapan khusus untuk melaksanakan nyacar. Persiapan yang dilakukan adalah mempersiapkan upacara dengan menyediakan kemenyan dan sesaji yang akan digunakan pada saat upacara.

Pada waktu yang telah ditentukan, seluruh peserta berkumpul di huma serang. Girang seurat mulai membaca doa sambil membakar kemenyan dan menghadapi sesaji. Setelah selesai menyampaikan doa, girang serat mulai melakukan pemotongan dahan-dahan yang berserakan di tanah, diikuti oleh warga masyarakat lainnya.

\section{Nukuh}

Kegiatan ini dilaksanakan setelah upacara nyacar dilakukan dan merupakan tahapan ketiga dalam mengolah huma. Dinamakan upacara nukuh yang berarti menebangi pohon-pohon besar yang tidak dipotong pada saat upacara narawas atau nyacar. Pelaksanaan nukuh dimaksudkan untuk memberi penyinaran matahari secara cukup terhadap tanaman padi yang akan ditanam. Pohon-pohon besar kerap kali menghalangi sinar matahari untuk sampai ke bawah.

Orang yang mendapat tugas untuk memimpin doa di huma serang adalah pu'un. Jika pu'un berhalangan dapat digantikan oleh orang yang ditunjuk oleh pu'un atau memiliki kedudukan yang dinilai sama dengan $p u^{\prime} u n$. 
Perlengkapan upacara yang dipersiapkan selain peralatan kerja yang berupa golok, juga sesaji. Sesaji yang disediakan terdiri atas congcot 'nasi yang dibentuk kerucut', telur ayam, bungabungaan, kain kafan, pisau kecil, dan kemenyan.

Acara diawali dengan meletakkan sesaji di sudut huma. Selanjutnya, pu'un membaca mantera di hadapan sesaji sambil memakan sirih. Setelah menyelesaikan pembacaan mantera, $p u$ 'un dan masyarakat Baduy yang hadir mulai melakukan pekerjaan menebangi pohon-pohon besar hingga pekerjaan selesai. Pekerjaan ini relatif menghabiskan waktu lama karena pohon-pohon besar ditebangi hanya menggunakan golok. Namun pekerjaan ini harus dilaksanakan sampai selesai.

Sesaji yang dipersembahkan menunjukkan penghormatan kepada para dangiang atau para makhluk halus yang menempati pohon-pohon besar untuk tidak terusik dan tidak mengganggu kepada pengolah huma dan tanaman yang ditanam. Oleh sebab itu, perangkat sesaji merupakan kesenangan atau benda-benda yang disukai oleh para dangiang. Dari upacara ini terkandung makna konservasi menyeluruh terhadap semua pendukung kelangsungan ekosistem (Senoaji, 2012: 283).

\section{Ngahuru}

Kata ngahuru mempunyai arti membakar. Pada ngahuru, ranting pohon dan rumput yang telah ditebang dan dipotong-potong pada upacara-upacara sebelumnya dibakar.

Waktu penyelenggaraan upacara ini kurang lebih lima belas hari setelah upacara nukuh. Penentuan waktu penyelenggaraan didasarkan pada perkiraan bahwa ranting pohon dan rerumputan telah kering dan bisa untuk dibakar. Waktu pelaksanaan biasanya dapat mundur apabila musim penghujan. Pada musim penghujan, ranting hasil menebang lebih lama kering. Penentuan waktu pelaksanaan tidak dikaitkan dengan hari-hari besar keagamaan atau kenegaraan, kecuali dengan hari baik untuk menggarap huma. Pelaksanaan kegiatan ini biasanya dimulai pada pagi hari dan berakhir pada siang hari.

Orang yang bertugas memimpin upacara ngahuru ini adalah pu'un. Ditunjuknya $p u$ 'un sebagai pemimpin upacara karena $p u$ 'un adalah orang pilihan yang mampu berkomunikasi dengan para dangiang. Berkomunikasi dengan para dangiang sangat diperlukan untuk menghindarkan dari hal-hal yang tidak diinginkan, seperti terbakarnya areal lain yang dapat menyebabkan kebakaran besar dan merugikan.

Tidak terdapat persiapan yang membutuhkan pengadaan khusus. Persiapan yang dilakukan oleh pu'un hanyalah pembacaan mantera di salah satu sudut huma serang. Perlengkapan yang dibawa dan digunakan lebih mengarah pada perlengkapan bekerja dibandingkan dengan peralatan upacara.

Teknis ngahuru diawali dengan pembacaan mantera oleh pu'un di salah satu sudut huma serang disaksikan oleh hadirin lainnya. Setelah selesai membacakan mantera, pu'un beserta orang yang lainnya mulai mengumpulkan pohon, ranting pohon, dan dedaunan yang telah kering. Barang-barang tersebut diatur tumpukannya agar mudah dan cepat habis dibakar. Pengelolaan kesuburan tanah tidak terbatas pada peningkatan kesuburan kimiawi, tetapi juga kesuburan fisik dan biologi tanah. Hal ini berarti bahwa pengelolaan kesuburan tanah tidak cukup dilakukan hanya dengan memberikan pupuk saja, tetapi juga perlu disertai dengan pemeliharaan sifat fisik tanah sehingga tersedia lingkungan yang baik untuk pertumbuhan tanaman, kehidupan organisme tanah, dan untuk mendukung berbagai proses penting di dalam tanah (Dresbøll dan Magid, 2006: 8).

\section{Ngaseuk}

Kegiatan ini disebut ngaseuk karena pekerjaan yang dilakukan di huma menggunakan aseuk atau penugal. 
Ngaseuk dilakukan untuk membuat lubang pada tanah guna disimpan benih padi. Dengan kata lain pada kegiatan ngaseuk dilakukan penanaman benih padi. Ngaseuk dilaksanakan dalam waktu dua hari pada bulan ketujuh atau bulan keempat perhitungan bulan Baduy.

Upacara ngaseuk dilakukan di dua tempat, yaitu leuit, lumbung padi tempat menyimpan padi dari huma serang dan di huma serang. Pemimpin upacara ngaseuk terbagi atas dua orang pada masing-masing jenis upacara. Penyediaan benih padi di leuit dipimpin oleh girang seurat, sedangkan upacara pada saat memulai penanaman benih padi di huma serang dipimpin oleh $p u^{\prime} u n$.

Persiapan ngaseuk telah dilakukan pada sore hari, sehari menjelang upacara ngaseuk dilaksanakan. Persiapan pada waktu itu berupa mempersiapkan sesaji yang terdiri atas minyak wangi, jeruk nipis, dan daun jawer kotok, sejenis tanaman perdu dengan daun mirip jengger ayam jantan. Pada sore hari itu juga, pembantu girang seurat mempersiapkan sesaji yang akan disertakan dengan benih padi. Kegiatan mempersiapkan sesaji dilaksanakan di halaman rumah girang seurat. Sesaji berupa seperangkat sirih, nasi tumpeng, minyak wangi, dan kemenyan.

Sore hari sebelum upacara ngaseuk dilaksanakan, istri girang seurat, melakukan ritual di leuit yang khusus untuk menyimpan padi dari huma serang. Pada ritual tersebut, ia menggunakan pakaian lengkap berupa kain dan kebaya. Di kolong leuit tersebut, ia meletakkan sesaji serapih mungkin. Setelah meletakkan sesaji, ia membaca mantera. Maksud upacara ini adalah ngahudangkeun pare, membangunkan padi yang sedang tidur agar mau dibawa ke tempatnya, yaitu huma.

Setelah membaca mantera, istri girang seurat mengambil beberapa ikat padi untuk dijadikan benih di huma serang. Padi tersebut dilepaskan dari tangkainya dengan menggunakan tangan, selanjutnya ditampi dan disimpan dalam bakul.

Pada malam hari, girang seurat bersama pembantunya melihat bintang kijang di langit. Setelah itu, dia mengeluarkan benih yang tersimpan di dalam rumah. Benih tersebut lalu diletakkan di halaman rumah beserta sesaji. Selanjutnya, sebanyak kurang lebih sembilan orang memainkan angklung sambil mengelilingi bakul yang berisi benih padi. Mereka memainkan angklung sambil membaca mantera. Inti mantera tersebut adalah kehendak manusia untuk mengawinkan Nyi Pohaci (dewi padi) di bumi, agar Nyi Pohaci hidup tenang dan tenteram berada di bumi. Dengan kata lain dengan mantera itu padi tumbuh subur selamanya di bumi. Setelah selesai membacakan mantera serta permainan angklung, benih padi dalam bakul dibawa masuk kembali ke dalam rumah girang seurat. Di dalam rumah benih padi dalam bakul ditempatkan di dekat kepala girang seurat sewaktu tidur.

Pada keesokan harinya, benih padi dalam bakul dibawa oleh girang seurat diiringi oleh empat orang pengiring dan pemain angklung. Empat orang pengiring dengan membawa kain putih menari-nari dengan iringan musik angklung. Sesampai di huma serang, benih padi dalam bakul bersama-sama dengan aseuk atau penugal diserahkan kepada pu'un. Setelah diberi mantera oleh pu'un, benih padi dan penugal disimpan di pupuhunan, dangau kecil untuk menyimpan sesaji. Di tempat tersebut pu'un, membaca mantera:

Mantera dalam Bahasa Baduy

"Amit kanu boga bumi, amit kanu boga bale,

turun ka Sang Rumuhun, menta-menta, kami rek netepkeun Pohaci Sang Hiyang Asri,

di buana panca tengah pasar Allah.

Pohaci Sang Hiyang Asri, ku kami rek ditetepkeun, ku kami rek diraramekeun, ku kami rek direremokeun, 
di bumi pratiwi, buana panca tengah.

Ulah geder, ulah reueus, mangka tetap mangka langgeng mangka hurip kajayaan.

Nu kosong pangeusikeun, nu celong pangminuhankeun.

Cokot dua cokot tilu, cokot tilu nungku-nungku datang opat yang ngajajar datang lima tanpa bilangan datang genep mangka ngariung mungpulung datang tujuh lilimbungan datang dalapan ngajajar datang salapan di buana panca tengah di bumi pratiwi"

Terjemahan Bebas:

Pamit kepada penguasa bumi pamit kepada yang empunya balai turun ke Sang Rumuhun (Tuhan) untuk meminta

kamu bermaksud menetapkan (memberi tempat) kepada pohaci Sang Hiyang Asri

di buana panca tengah pasar Allah.

Pohaci Sang Hiyang Asri

akan kami tetapkan

akan kami bahagiakan

akan kami jodohkan

di bumi pertiwi

buana panca tengah.

Jangan sedih (ragu) jangan takabur hendaknya tetap, hendaknya langgeng agar hidup mendapatkan kejayaan

Yang kosong tolong diisi yang tidak penuh agar dipenuhkan

Ambil dua, ambil tiga ambil tiga tidak berpasangan datang empat berderet berjajar datang lima tanpa hitungan datang enam agar berkumpul-kumpul datang tujuh berkerumun datang delapan berjajar

datang sembilan di buana panca tengah

di bumi pertiwi

(Suhandi, Abdurahman, Ruswandi, 1986: 75).

Setelah pu'un selesai membacakan mantera tersebut, kemudian dia melakukan mitembeyan melak, penanaman pertama sambil duduk bersila dan memakan sirih. Penaburan benih dilakukan di dekat pungpuhunan. Benih padi yang ditanam atau ditaburkan kurang lebih sebanyak dua belas butir. Benih padi ditaburkan dengan letak sedemikian rupa hingga mirip dengan bentuk kepala, leher, dan badan Pohaci Sang Hiyang Asri. Setelah pu'un selesai melakukan mitembeyan melak, peserta lain yang berada di dalam huma serang melakukan tindakan serupa dengan pu'un walaupun benih padi tidak dibentuk seperti badan Pohaci Sang Hiyang Asri.Upacara ngaseuk yang dilaksanakan di huma serang menandai penanaman padi di huma-huma lainnya milik masyarakat. Masyarakat atau penduduk Baduy tidak perlu melakukan upacara serupa. Selain keharusan untuk memulai penanaman padi di pupuhunan.

Selain pantangan yang berlaku pada upacara ngaseuk di huma serang, yakni tidak boleh meludah, merokok, kentut, dan berbicara kotor. Terdapat juga keharusan yang harus dilaksanakan pada saat upacara ngaseuk, yakni pada saat menyimpan sesaji di kolong leuit, istri girang seurat harus memakai pakaian lengkap; di huma serang, laki-laki harus menggunakan iket; pada saat ngaseuk di huma serang, lakilaki harus sambil mengunyah sirih.

\section{Ngirab Sawan}

Nama kegiatan tersebut adalah ngirab sawan. Dikatakan demikian karena kata ngirab artinya menghalau dan kata sawan artinya hama. Jadi kegiatan ngirab sawan adalah kegiatan serta upacara untuk menghalau hama tanaman. Dengan kegiatan ngirab sawan hama padi dapat diberantas, dengan terbebasnya padi dari hama maka tanaman padi akan tumbuh 
subur dan berbulir banyak. Selain memberantas hama padi, ngirab sawan ini akan menyuburkan tanah karena pada acara ini ditaburkan ramuan dari berbagai daun yang dapat menyuburkan tanah.

Upacara dan kegiatan ngirab sawan dilakukan setelah padi yang ditanam berumur kurang lebih empat puluh hari sejak padi ditanam. Pada usia ini, padi telah tumbuh dan mulai mengeluarkan pucuk daun. Pada saat-saat inilah biasanya hama padi akan datang menyerang. Penentuan hari pelaksanaan upacara berdasarkan hasil musyawarah para sesepuh adat dengan melihat perkembangan padi, tentu saja dipertimbangkan pula hari-hari yang tidak melanggar hari pantangan untuk melakukan pekerjaan di huma.

Persiapan yang dilakukan berupa pencarian dedaunan dan pembuatan ramuan pembasmi hama serta penyediaan perlengkapan upacara. Perlengkapan upacara terdiri atas ramuan yang terbuat dari dedaunan dan bahan alami lainnya serta sesaji. Ramuan terdiri atas bermacam buah-buahan dan dedaunan seperti buah jeruk nipis, kelapa hijau, daun hanjuang, daun seel, areuy beureum, tanaman menjalar, lengkuas yang ditumbuk halus dicampur abu dapur. Sesaji yang dibuat berupa congcot 'nasi yang berbentuk kerucut', telur ayam, bunga rampai, sirih, dan kemenyan.

Awal pelaksanaan upacara dimulai dengan meletakkan sesaji di salah satu sudut huma serang oleh girang seurat. Setelah menyimpan sesaji, girang seurat membaca mantera. Selesai membaca mantera, girang seurat menaburkan ramuan ke daun padi yang ada di huma serang. Daun padi yang paling awal ditaburi ramuan adalah daun-daun padi yang berada di pungpuhunan.Jika terdapat daun padi yang telah terkena hama maka daun padi tersebut akan diubaran, diobati dengan cara memotong daun padi yang terkena hama dengan menggunakan sabit atau pisau. Daun padi yang terkena hama dan telah dipotong dibuang ke lubang sampahakan busuk dan mengering terkena panas dan hujan sekaligus hama-hama yang menempel di daun padi tersebut mati.

\section{Mipit}

Tahap berikutnya dinamakan mipit berarti upacara memetik atau menuai dalam ungkapan bahasa yang halus. Pada kegiatan ini padi yang telah menguning dipanen atau dituai. Dalam kegiatan ini tidak dapat dilakukan pemetikan dengan sembarangan. Sikap berupa perlu adanya pengkhususan perlakuan terhadap padi yang dipetik merupakan hal yang dianggap paling utama. Sikap mengkhususkan tersebut berupa pemotongan padi harus diawali dengan menuai padi yang berada di pungpuhunan yang berbentuk orang. Setelah itu barulah dibolehkan untuk menuai padi di huma serang pada bagian lainnya.

Waktu penyelenggaraan acara mipit sangat bergantung pada keadaan buah padi. Hanya padi yang cukup tualah yang boleh dipanen. Dengan demikian, penentuan waktu untuk mipit ditentukan secara pasti atau ditentukan pada waktu sebelumnya. Penentuan waktu mipit secara pasti ditentukan kemudian setelah melihat padi boleh dituai. Sekalipun demikian, penentuan waktu melalui musyawarah kokolot Baduy. Kepastian untuk mipit biasanya hanya beberapa hari setelah padi siap dipanen. Jika waktu mipit terlalu lama dengan keadaan padi yang sudah tua pun, hal ini kurang menguntungkan karena padi dapat rontok atau dimakan burung.

Pada hari yang ditentukan, upacara mipit dipimpin oleh girang seurat. Girang seurat ditugaskan untuk memimpin upacara tersebut secara turun-temurun dari satu girang seurat yang satu kepada girang seurat pengganti berikutnya. Hal tersebut menjadi terpolakan karena salah satu tugas girang seurat memimpin upacara yang berkaitan dengan pertanian di huma.

Tiga hari sebelum mipit dilakukan acara ngukus yaitu membakar kemenyan dan menyediakan sesaji berupa nasi congcot, nasi berbentuk kerucut, sirih 
selengkapnya, telur ayam, pisau kecil, bunga rampai, kain kafan dan kemenyan di pungpuhunan lalu menyimpannya.

Pada hari yang ditentukan, pagi-pagi sebelum mipit dilaksanakan, girang seurat mulai membaca doa di pungpuhunan. Setelah selesai membaca doa, mulailah girang seurat melakukan pemetikan padi menggunakan ani-ani. Padi yang pertama kali dipetik harus padi yang berada di pungpuhunan dan merupakan padi pertama yang ditanam oleh pu'un pada saat ngaseuk, yang ditanam dengan letak benih padi menyerupai kepala manusia, yang bermakna kedekatan antara manusia dan lingkungannya (Iskandar and Ellen, 1999: 97); (Permana, Nasution, and Gunawijaya, 2011: 67).

Padi yang telah dipetik oleh girang seurat kemudian disimpan oleh istri girang seurat di dangau huma serang. Penyimpanan padi tersebut dilakukan dengan sangat hati-hati. Setelah penyimpanan padi tersebut, maka acara mipit selesai. Selanjutnya, dilakukan pemetikan padi lainnya yang berada di huma serang. Pemetikan padi lainnya disebut dibuat. Cara-cara menuai padi, peralatan yang digunakan untuk menuai, sampai cara penyimpanan yang sedemikian rupa, membuktikan penjagaan yang khusus terhadap jenis padi yang biasa ditanam.

\section{Dibuat}

Arti kata dibuat adalah memetik padi di huma serang. Kata dibuat disampaikan dalam bahasa tingkatan sedang. Kegiatan dibuat dilakukan pada padi di bagian lain selain yang di pungpuhunan dan dilakukan setelah mipit selesai. Menuai atau pemetikan padi pada dibuat pun harus dilakukan dengan sangat hati-hati, tidak boleh sembarangan dan bahkan tidak boleh satu butir padi pun yang jatuh ke tanah. Dibuat dilaksanakan setelah acara mipit selesai yakni pada pagi hari sekitar pukul 09.00. Mipit dan dibuat diusahakan untuk dilaksanakan sepagi mungkin agar pekerjaan cepat selesai sebelum panas karena terik sinar matahari atau sebelum hujan turun. Orang yang ditunjuk untuk memimpin upacara ini adalah girang seurat. Penunjukan dilaksanakan secara turun-temurun. Bila girang seurat berhalangan karena sakit atau meninggal maka tugasnya digantikan oleh orang pilihan yang dianggap memiliki kemampuan yang sama.

Upacara dibuat dilakukan dan berkaitan dengan upacara mipit. Oleh sebab itu, persiapan dan perlengkapan upacara yang dilakukan masih sama. Hal yang membedakan antara mipit dan dibuat hanya pada urutan pemetikan padi saja.

Setelah selesai prosesi mipit, kaum perempuan Baduy Kajeroan dan Baduy Panamping mulai melakukan penuaian padi. Mereka menuai padi dengan menggunakan ani-ani. Menuai padi dengan menggunakan ani-ani hanya memotong bagian batang padi. Padi yang telah dipotong digenggam menggunakan tangan kiri, sementara tangan kanan terus memotong batang padi. Setelah padi yang dipotong terkumpul satu genggaman, padi tersebut diletakkan. Demikian seterusnya sampai seluruh padi yang ada di huma habis dipotong, barulah batang-batang padi dalam ukuran rata-rata genggaman orang dewasa diikat. Memotong padi dilakukan dengan cara berjalan maju. Awal memotong padi dilakukan pada padi yang berada di sudut-sudut huma dan terus mengarah ke padi-padi yang terletak di perbatasan pungpuhunan. Memetik padi dengan cara itu merupakan salah satu pantangan lainnya yang harus dilakukan dalam menuai padi di huma serang. Ketentuan tersebut tidak boleh dilanggar. Jika dilanggar akan mendapat bebendon berupa kecelakaan atau hasil huma tidak banyak.

\section{Nganyaran}

Kata nganyaran berasal dari kata anyar atau baru. Nganyaran dapat diartikan mengawali sesuatu dengan yang baru. Tujuan kegiatan nganyaran adalah menandai pengolahan padi yang baru dipanen menjadi beras. Hal ini perlu 
dilakukan dengan cara khusus agar pengolahan padi yang baru dipanen berbeda dengan pengolahan pada padi-padi selanjutnya.

Melakukan acara nganyaran harus dilakukan setelah padi benar-benar kering dengan cara ditumbuk pada lesung menggunakan alu. Jika tidak, padi yang ditumbuk akan menghasilkan beras yang hancur. Padi dikeringkan di lantayan yang pengeringannya hanya mengandalkan panas sinar matahari. Apabila matahari bersinar penuh sepanjang hari, padi ikatan yang disusun di lantayan dapat kering dalam waktu dua minggu. Sebaliknya, pada musim penghujan, padi akan mengering sampai tiga minggu bahkan satu bulan. Setelah padi kering itulah upacara nganyaran dilaksanakan. Acara dimulai pada pagi hari sampai dengan selesai. Upacara nganyaran dilakukan di saung lisung milik adat. Tempat ini tidak boleh tergantikan oleh tempat lainnya sekalipun saung lisung banyak tersebar milik masyarakat.

Upacara nganyaran dilaksanakan oleh lima orang perempuan. Para pelaku tersebut terdiri atas istri pu'un 'istri ketua adat', istri girang seurat 'istri pelaksana upacara', istri jaro tangtu istri ketua kampung Baduy Dalam', istri baresan 'istri dewan penasihat', dan istri pu'un pareman 'istri bekas pu'un'. Kelima orang perempuan tersebut diusahakan harus menghadiri upacara tersebut. Jika salah seorang tidak dapat hadir maka posisinya akan digantikan dengan pengganti yang ditentukan oleh adat.

Perlengkapan yang harus dipersiapkan sebelumnya dalam upacara nganyaran adalah lima ikat padi hasil dari huma serang, alu, lesung, bakul, niru, kain putih, dan minyak wangi. Padi merupakan objek yang akan ditumbuk; alu dan lesung merupakan alat menumbuk padi; niru digunakan untuk menampi padi yang baru selesai ditumbuk; bakul digunakan untuk menempatkan beras hasil menumbuk; kain putih digunakan untuk menutup bakul berisi beras; dan minyak wangi disimpan di atas bakul yang ditutupi kain putih.

Tata cara nganyaran adalah, padi yang sudah kering yang berada di lantayan dibawa ke saung lisung. Padi tersebut diletakkan di sepanjang lesung. Setelah membaca mantera atau doa, mulailah kelima orang perempuan, istri para sesepuh Baduy menumbuk padi. Sebelum mulai menumbuk, alu yang akan digunakan untuk menumbuk padi harus diusap dengan ludah. Pantangan yang berlaku dalam nganyaran adalah dalam melakukan nutu 'menumbuk' tidak boleh sambil bergurau dan banyak bercakap-cakap, apalagi pembicaraan yang kotor dan jelek. Para pelaku ini akan banyak diam, mereka berbicara seperlunya dan jika diperlukan benar.

Beras bersih hasil tumbukan ditempatkan pada lima bakul yang telah tersedia, kemudian masing-masing bakul ditutupi kain putih. Di atas kain putih diletakkan minyak wangi. Selanjutnya kelima bakul tersebut dibawa ke rumah girang seurat atau pelaksana upacara untuk diinapkan. Keesokan harinya, beras tersebut dimasak dijadikan nasi tumpeng. Setelah matang, nasi tumpeng tersebut dibawa ke bale 'balai' untuk dimanterai oleh pu'un. Setelah itu, tumpeng dibagikan kepada yang hadir untuk dimakan bersama-sama. Nasi dibagikan oleh palawari 'pembantu pelaksana upacara'. Makan tumpeng diakhiri dengan ngalemar 'makan sirih'. Palawari pun membagikan tumpeng lainnya kepada penduduk Baduy Dalam atau Urang Tangtu. Dengan demikian, seluruh penduduk merasakan tumpeng yang berasal dari beras baru.

Di Balai pun disimpan padi hasil panen dari huma serang yang dapat dibawa pulang oleh masing-masing yang hadir. Padi yang dibawa pulang hanya sebagai syarat 'memenuhi ketentuan adat'. Oleh karena itu, padi yang dibawa hanya berjumlah beberapa butir. Padi yang disediakan untuk dibawa tadi tidak boleh dibawa pulang sampai habis dalam tempatnya melainkan harus disisakan. 
Butiran padi yang disisakan di Balai, merupakan perlambang bahwa hasil panen diharapkan melimpah, hingga panen berikutnya tiba padi masih tersisa di leuit 'lumbung padi'.

Upacara nganyaran merupakan lambang ungkapan terimakasih kepada Batara Tunggal dan kepada karuhun 'leluhur' yang telah memberikan rezeki kepada mereka. Selain itu, dengan nganyaran dianggap pertanda bahwa orang Baduy dibolehkan untuk memakan hasil panen untuk merasakan jerih payah mereka dalam mengolah huma. Dengan memakan hasil panen, mereka dapat menilai tentang kualitas dan kuantitas padi yang ditanamnya.

\section{PENUTUP}

Mencermati pola hidup orang Baduy dalam memperlakukan tanah (huma) begitu hormat dan taat aturan dari para leluhurnya. Mereka tidak mau gegabah mengubah aturan yang sudah terpolakan. Ketaatan tersebut atas dasar bukti yang menunjukkan tidak pernah terjadi kekurangan pangan, dalam hal ini padi atau beras. Mereka pun tidak mencoba melanggar aturan dengan cara mengeksploitasi tanah di luar ketentuan yang berlaku, pamali atau tabulah yang mengikat dan dijadikan norma hukum yang harus mereka patuhi.

Huma serang menjadi tolak ukur bagi huma-huma lainnya. Untuk itu, masyarakat akan mengolah huma mereka menuruti pola-pola yang dilakukan huma serang. Keberhasilan panen padi di huma serang yang disebabkan pelaksanaan upacara dan tata kelola yang sesuai aturan turut pula menentukan keberhasilan panen padi di huma-huma penduduk, begitu juga sebaliknya.

Pengetahuan lokal tentang kondisi tanah di tatar Baduy sudah mereka kuasai sebelum ditemukan oleh para peneliti bahwa tanah di Baduy berupa bebatuan yang labil. Para pendahulu orang Baduy yang hidup beberapa puluh tahun yang lalu telah mengetahui kondisi tersebut. Dengan demikian, mereka lalu membuat larangan yang berbentuk tabu untuk menggarap tanah dengan cara-cara yang dapat menimbulkan tanah longsor seperti tidak membuat sawah atau kolam di wilayah Baduy. Pengetahuan mengenai lapisan tanah yang subur pada bagian permukaan diwujudkan dengan larangan menggarap lahan dicangkul cukup dengan ditugal, tidak boleh diinjak kerbau dapat diartikan tanah tidak dibajak. Jika huma dibolehkan untuk dicangkul atau dibajak, besar kemungkinan unsur top soil yang sangat dibutuhkan oleh padi dalam petumbuhannya akan terlampaui, berganti dengan lapisan tanah yang tidak mengandung zat nutrisi.

Kearifan lokal tentang penjagaan tanah yang mereka pakai, secara tidak langsung bukan hanya menekankan pada aturan yang bersifat fisik-material berupa tata cara pengolahan tanah huma, melainkan menekankan juga pada perubahan psikologis untuk membentuk karakter manusia yang baik dan terpuji. Hal-hal yang dilarang terkait dengan fisik material, hanya terjadi pada pelarangan beberapa tindakan, seperti tidak boleh merokok di huma, huma tidak boleh dicangkul, huma tidak boleh diinjak kerbau, huma tidak boleh dibajak, serta pelarangan hari-hari tertentu untuk bekerja di ladang dan huma, serta urutan upacara yang tidak boleh ditukarkan. Tujuan dari pembatasan ini adalah mengurangi input untuk produksi sebagai salah satu penerapan konsep "low carbon society".

Kearifan lokal yang terkait dengan sikap kejiwaan ditunjukkan dengan sikapsikap yang dilarang dilakukan di huma yang selintas tidak terkait langsung dengan kondisi tanah huma. Larangan tersebut di antaranya pakaian yang harus dikenakan di huma oleh kaum laki dan perempuan, dilarang kentut, dilarang berkata kotor, tidak boleh meludah. Jika diperhatikan secara saksama, larangan-larangan tersebut tidak terkait langsung dengan perubahan kondisi tanah huma, tetapi berkaitan dengan pembentukan sikap untuk menjadi 
orang yang arif, selalu mematuhi segala aturan, selalu menghargai ciptaan Sang Maha Pencipta, dan lain sebagainya. Dengan pembentukan karakter secara tidak langsung seperti itu, menggunakan huma sebagai media penyampaiannya merupakan teknik-teknik pembentukan karakter orang Baduy yang efektif dan santun. Mereka tidak merasa digurui atau diajari tentang sikap moral oleh seseorang. Jika hal ini terjadi dan disadari, bisa saja ajaran tersebut tidak diterima. Penerimaan petuah, ajaran, atau nasihat sangat bergantung pada figur penyampainya bukan pada ajaran yang disampaikannya. "Ancaman" keras akibat pelanggaran tertuang dalam bebendon akibat pelanggaran terhadap pamali atau tabu. "Ancaman" tersebut sangat membuat takut setiap pelanggarnya, karena akibat yang akan terjadi sangat merugikan dan tidak dikehendaki oleh semua orang Baduy, misalnya berupa kegagalan dalam bertani atau gagal panen, menderita sakit, bahkan datangnya kematian. Hal tersebut bukan hanya mengena kepada perorangan, bisa juga melanda seluruh masyarakat.

Sikap hati-hati dan rendah hati orang Baduy dalam menghargai benda-benda selain manusia seperti pohon besar, batubatuan asli, air, dan benda mati lainnya, terlebih terhadap padi yang dianggapnya penjelmaan dari Dewi Sri sangat tinggi. Benda-benda tersebut dipersonifikasi sebagai makhluk hidup atau dimiliki oleh penunggu yang gaib. Sebagaimana layaknya makhluk hidup, mereka dapat mengajak berbicara benda-benda tersebut. Mereka selalu meminta izin terlebih dahulu kepada benda-benda tersebut apabila akan diperlakukan tertentu. Kepada Dewi Sri yang dianggap menjelma sebagai padi, perlakuannya lebih dikhususkan. Dewi Sri, ditempatkan di tempat khusus, digendong, dikawinkan, dan dimohon untuk betah tinggal di bumi. Dengan kedekatan seperti ini, mereka memiliki anggapan bahwa akan berlaku hukum timbal balik. Apabila kita berbuat baik kepada benda-benda maka benda-benda pun akan berbuat baik kepada kita. Sebaliknya jika benda-benda tersebut tidak diperlakukan dengan baik maka bendabenda itu pun akan memberi hal yang sama dengan yang telah mereka lakukan. Sikap seperti itu pun merupakan keyakinan dan rasa percaya yang tinggi terhadap Sang Pencipta. Mereka meyakini bahwa semua yang ada di bumi ini diciptakan oleh Sang Pencipta tentu memiliki maksud dan makna. Mereka pun meyakini bahwa semua makhluk di bumi ini harus hidup dan berjalan selaras, berlaku hukum simbiosis mutualistis. Di antara semua makhluk harus saling menghormati, saling menjaga dan tidak boleh saling menyakiti. Baik buruknya atau bermanfaat dan tidak suatu ciptaan bergantung kepada kita yang menerimanya.

Sesaji yang disediakan menunjukkan sikap menghormati kepada leluhur yang sudah meninggal dan semasa hidupnya memiliki jasa yang besar dalam kehidupan mereka sekarang. Perangkat sesaji yang disediakan merupakan kesukaan para leluhur sewaktu masih hidup. Kain kafan atau bagiannya terdapat pula dalam perangkat sesaji. Hal ini memiliki makna simbolik sebagai pengingat kepada yang masih hidup bahwa mereka akan mati dan dikubur dengan berbungkus kain kafan. Dalam menghadapi kematian inilah warga Baduy harus selalu baik terhadap sesama manusia dan benda-benda ciptaan Sang Hyang. Warna putih pada kain kafan pun dapat dimaknai sebagai sesuatu yang putih, bersih dan suci. Lambang warna ini dapat digunakan dalam hidup sehari-hari, yakni dalam menjalani kehidupan harus selalu dilandasi oleh hati yang putih, bersih, menghindarkan diri perasaan iri dan dengki. Tidak boleh iri akan rezeki orang lain karena di antara warga Baduy memiliki usaha yang sama. Jika hasil dari usaha yang mereka lakukan berbeda, semata-mata hanya pemberian dari Yang Pemberi Rezeki yang berbeda untuk tiap orang.

Hal-hal tersebut pada uraian sebelumnya pada kenyataan hidup sehari- 
hari bukan hanya berlaku pada huma dan lingkungan alam lainnya, tetapi akan terbawa dan teraplikasi dalam hubungan hidup sehari-hari dalam interaksi sosial dengan sesama manusia di mana pun. Termasuk di dalamnya penghargaan terhadap jabatan dan pelaksanaan kewenangan kepada pemimpin adat mereka.

Leuit (lumbung padi) orang Baduy baik milik keluarga atau milik adat tidak pernah kosong oleh padi. Sistem pendistribusian padi ke dalam leuit yang menggunakan sistem distribusi bersirkulasi menyebabkan pengawasan atau pengontrolan cadangan padi dapat terlihat pada saat setiap mengambil padi untuk ditumbuk. Mereka akan mengambil padi untuk ditumbuk secukupnya, cukup untuk makan sekeluarga dalam waktu beberapa hari ke depan. Tidak pernah terpikir untuk mengambil padi berlebihan. Dalam benak mereka cukup mengambil seperlunya. Jika masih diperlukan, mereka dapat mengambil dengan mudah di leuit. Bukan sesuatu yang aneh jika persediaan pangan berupa padi di leuit bukan hanya cukup untuk jangka waktu satu atau dua musim, tetapi bisa untuk beberapa musim. Tidak mengherankan jika dalam leuit terdapat padi yang sudah tersimpan hampir tujuh tahun. Padi tersebut tidak busuk dan tidak hancur ketika ditumbuk. Padi lama tersebut ketika ditumbuk hanya menghasilkan beras yang berubah warna tetapi rasa tetap sama dengan beras-beras baru dan tetap enak untuk dimakan.

Penggunaan bibit padi jenis lokal terus dipertahankan karena kehandalannya dalam menangkis serangan hama dan banyaknya padi yang dihasilkan telah terbukti selama puluhan tahun sejak orang tua mereka. Mereka tidak mau mencari bibit baru apalagi untuk berspekulasi dengan bibit baru yang belum tentu unggul. Cerita dan pengalaman yang diperoleh mereka dari daerah lain tentang bibit dengan varietas baru yang kurang memenuhi harapan, menambah mereka bertambah enggan mengganti bibit padinya. Hal ini bermakna bahwa orang Baduy sangat menjaga ketersediaan sumber daya genetik untuk kelangsungan hidup manusia.

Sistem pertanian yang terpadu antara kandungan unsur hara yang tersedia dalam tanah, cara-cara mengolah tanah yang teratur, serta bibit padi lokal yang digunakan telah membentuk satu kesatuan yang kuat dalam menghasilkan padi berkualitas. Ketiga unsur dalam satu kesatuan ini tidak boleh dipisahkan satu dengan unsur lainnya.

Pengendalian diri yang sudah terbentuk dan teruji serta kepatuhan terhadap aturan yang berupa pamali, telah menghasilkan pembentukan sikap untuk melakukan kalkulasi secara cermat. Sikapsikap tersebut terlihat pada kepatuhan pada aturan untuk tidak menghabiskan padi yang disimpan di Balai atau di leuit. Bagaimana pun tingginya keinginan untuk membawa pulang padi tersebut atau menghabiskan padi di leuit tetap dapat dikendalikan oleh diri sendiri yang telah terbentuk sikap kedisiplinannya. Ukuran kepuasan mereka terhadap perolehan hasil panen sangat sederhana dan wajar, yaitu dengan takaran melalui ukuran isi perut dalam memakan nasi yang tentu saja memiliki kapasitas yang terbatas. Larangan untuk hidup berlebihan menyebabkan mereka tidak berlomba-lomba melakukan diversifikasi tanaman padi di huma dalam menghasilkan padi yang lebih banyak. Huma dioptimalkan dengan cara mengutamakan untuk menanam padi dan beberapa tanaman sela yang tidak mengganggu pertumbuhan tanaman padi dan kesuburan tanah. Tanaman sela yang ditanam biasanya berupa tanaman-tanaman yang dapat mengenyangkan perut selain nasi, serta tanaman empon-empon yang berguna sebagai bumbu dapur. Cara ini sebagai upaya tidak langsung dalam menjaga ketahanan padi atau beras.

Orang Baduy tidak boleh atau pantang untuk menjual padi atau beras hasil panen, termasuk menjual nasi. Karena padi dihasilkan oleh 'lahan suci'. 
Malahan mereka dibolehkan untuk memberi padi atau beras kepada orang lain dalam jumlah yang disesuaikan. Kearifan ini bermakna pengendalian diri untuk tidak memiliki uang secara berlebihan. Biasanya orang yang telah memiliki uang secara berlebihan akan membelanjakan uang tersebut untuk hal-hal yang tidak bermanfaat dalam hidup. Kemungkinan lainnya mereka akan hidup umaing 'sombong', merasa dirinya lebih berada dari orang lain.

Penelitian ini memberikan tiga rekomendasi yaitu (i) perlu dilakukan usaha terpadu yang menjamin keberlangsungan penerapan kearifan lokal dengan memerhatikan kemajuan ilmu pengetahuan dan teknologi untuk mendukung swasembada pangan; (ii) program pemerintah dalam swasembada pangan harus mengacu pada daya dukung lingkungan; (iii) menyusun tata ruang berdasarkan potensi penggunaan lahan dan kajian sosial budaya.

\section{DAFTAR SUMBER}

\section{Buku}

Ekajati, S, Edi. 1995.

Kebudayaan Sunda (Suatu Pendekatan Sejarah) Jakarta: Pustaka Jaya

Mustapa, Hasan. 2010. Adat Istiadat Sunda. Bandung: Alumni.

Rosidi, Ayip. 2000. Ensiklopedi Sunda, Alam, Manusia, dan Budaya, Termasuk Budaya Cirebon dan Betawi. Jakarta: Balai Pustaka.

Sam Suhandi, Abdurahman, Ruswandi. 1986. Tata Kehidupan Masyarakat Baduy di Provinsi Jawa Barat. Bandung: Proyek Inventarisasi dan Dokumentasi Kebudayaan Daerah, Depdikbud.

Tim Redaksi KBBI. 2013.

Kamus Besar Bahasa Indonesia, Pusat Bahasa Depdiknas, Edisi Keempat, Jakarta: Gramedia Pustaka Utama.

Zeng, Shihong. 2011.

Literature Review of Carbon Finance and Low Carbon Economy for Constructing
Low Carbon Society in China. Low Carbon Economy 02 (01), 2011.

\section{Jurnal, Makalah}

Berkes, Fikret., Johan Colding and Carl Folke. "Rediscovery of Traditional Ecological Knowledge as Adaptive Management". Dalam Ecological Applications 10(5), 2000 .

Chakravarty, R.

"Preserving Traditional Knowledge: Initiatives in India". IFLA Journal, 2010.

Dresbøll, Dorte Bodin and Jakob Magid. "Structural Changes of Plant Residues during Decomposition in a Compost Environment" dalam Bioresource Technology 97(8), 2006.

Iskandar, Johan and Roy Ellen.

"In Situ Conservation Of Rice Landraces Among The Baduy Of West Java." Journal of Ethnobiology 19 (1), 1999.

Khomsan, Ali, and Winati Wigna.

"Sosio Budaya Pangan Suku Baduy." Jurnal Gizi Dan Pangan 4 (2), 2009.

Octavia Dona, Andriani Susi, Qirom Abdul, Azwar Fatahul.

"Keanekaragaman Jenis Tumbuhan sebagai Pestisida Alami di Savana Bekol Taman Nasional Baluran". Jurnal Penelitian Hutan dan Konservasi Alam, Pusat Penelitian dan Pengembangan Hutan dan Konservasi Alam, Bogor.

Patel, Raj.

"The Long Green Revolution." Journal Of Peasant Studies 40 (1): 1-63, 2012.

Permana, E., I. Nasution, and J. Gunawijaya.

"Kearifan Lokal tentang Mitigasi Rencana pada Masyarakat Baduy" dalam MAKARA, Sosial Humaniora 15 (1).

Rosen, Franciska, and Per Olsson. "Institutional Entrepreneurs , Global Networks , and the Emergence of International Institutions for EcosystemBased Management: The Coral Triangle Initiative.” Marine Policy 38, 2013.

Senoaji, Gunggung.

"Pengelolaan Lahan Dengan Sistem Agroforestry oleh Masyarakat Baduy di 
Banten Selatan." Jurnal Bumi Lestari

Volume 12, 2012.

Zamroni, Imam.

"Perubahan Sosial-Budaya Petani Organik di Yogyakarta." Jurnal Masyarakat dan Budaya, LIPI. Jakarta. 2010.

\section{Internet}

Adimihardja, Kusnaka. 2000.

"Orang Baduy di Banten Selatan:

Manusia Air Pemelihara Sungai”, dalam

Antropologi Indonesia 61(1), diakses dari http://anthropology.fisip.ui.ac.id/httpdocs/ jurnal/2000/61/full/06ka61.pdf. 